\title{
Identification of Tomato Leaf Factors that Activate Toxin Gene Expression in Pseudomonas syringae pv. tomato DC3000
}

\author{
Xiu-Zhen Li, Alvin N. Starratt, and Diane A. Cuppels
}

Agriculture and Agri-Food Canada, Southern Crop Protection and Food Research Centre, 1391 Sandford Street, London, Ontario N5V 4T3 Canada. Accepted for publication 8 July 1998.

\begin{abstract}
Li, X.-Z., Starratt, A. N., and Cuppels, D. A. 1998. Identification of tomato leaf factors that activate toxin gene expression in Pseudomonas syringae pv. tomato DC3000. Phytopathology 88:1094-1100.

Coronatine is a non-host-specific chlorosis-inducing phytotoxin produced by the tomato and crucifer pathogen Pseudomonas syringae pv. tomato DC3000. How the chromosomal gene cluster controlling toxin synthesis in this strain is regulated in planta is unknown. Ice nucleationactive cor:inaZ marker-exchange derivatives of strain DC3000 were used to determine coronatine gene expression in various host and nonhost plants and in a minimal medium supplemented with selected tomato plant constituents. Ice nucleation activity, which was first detected $4 \mathrm{~h}$ after inoculation, was highest in cabbage, tomato, and soybean and lowest in melon

and cucumber. No correlation existed between bacterial population size and expression level on the various plants. Crude tomato leaf extract and intercellular fluid were strong inducers of toxin synthesis. Based on highperformance liquid chromatography analyses and bioassays, we concluded that the active components of both preparations were malic and citric acids, with minor contributions coming from shikimic and quinic acid. Although several compounds including glucose and inositol activated the toxin genes when tested at high concentrations ( 3 to $5 \mathrm{mM}$ ), shikimic and quinic acids were the only ones with activity at concentrations below $0.1 \mathrm{mM}$. Neither acid could be used as a sole carbon source by strain DC3000. The signal activity of shikimic acid was enhanced 10 -fold by the addition of glucose. None of the plant phenolics that we screened affected coronatine gene expression.
\end{abstract}

Many strains belonging to the Pseudomonas syringae pathovars glycinea, morsprunorum, atropurpurea, tomato, and maculicola produce the non-host-specific phytotoxin coronatine (COR) $(7,18,19$, 41). This toxin, which is formed by the coupling of coronamic acid (CMA) with the polyketide coronafacic acid (CFA) (28) via an amide bond, causes leaf chlorosis and plant stunting. Recent work has shown that COR, unlike most other chlorosis-inducing phytotoxins, does not destroy organelles or disrupt membrane systems (26); how it acts at the molecular level remains unknown. Palmer and Bender (26) hypothesize that the toxin enhances virulence by causing the plant cell to leak substances that act as nutrients for the bacteria, thereby improving their ability to survive and multiply. Earlier work had shown that $P$. syringae pv. tomato mutants that are unable to synthesize COR produce small lesions and do not multiply as rapidly as the wild type on leaf surfaces (3).

COR biosynthesis is controlled by a large gene cluster (approximately $30 \mathrm{~kb}$ ) that is located on the chromosome in $P$. syringae pv. tomato DC3000 and many pathovar maculicola strains, but is on a large plasmid in most pathovar tomato and glycinea strains $(2,7$, $17,24,43)$. Although this cluster is highly conserved, significant differences in restriction fragment length polymorphism patterns between plasmid-borne and chromosome-borne clusters have been noted. In P. syringae pv. glycinea PG4180, CMA and CFA synthesis is thermoregulated via a modified two-component regulatory system consisting of $\operatorname{cor} P$ and $\operatorname{corR}$, which appear to be response regulators, and corS, which acts as an environmental sensor $(15,39)$.

Using high-performance liquid chromatography (HPLC) to measure COR levels and dry weight to estimate bacterial growth, Palmer and Bender (25) demonstrated that COR production in a basal medium is significantly affected by osmolarity, incubation

Corresponding author: D. A. Cuppels; E-mail address: cuppelsd@em.agr.ca

Publication no. P-1998-0811-02R

(C) 1998 For the Department of Agriculture and Agri-Food, Government of Canada, Minister of Public Works and Government Services Canada temperature, carbon source, $\mathrm{FeCl}_{3}$ and $\mathrm{KNO}_{3}$ concentration, the presence of complex carbon-nitrogen sources, and amino acid supplementation. Plant-derived secondary metabolites and soybean plant extracts had no effect on COR levels. In later work, using Tn5-gusA5 transcriptional fusions to the COR gene cluster, they confirmed the negative effect of high temperature, fructose, xylose, isoleucine, and valine on toxin synthesis, but found that high osmolarity or the addition of complex carbon-nitrogen sources did not significantly impact the transcriptional activity of the promoter regions of the $c m a A / T$ or $c f l / C F A$ operons (27). These results differ from those obtained with the hrp (hypersensitive reaction and pathogenicity) and $a v r$ (avirulence) genes of $P$. syringae and Xanthomonas axonopodis pv. vesicatoria, whose expression is suppressed in media containing high levels of various complex carbonnitrogen sources $(32,34,40,42)$.

Numerous studies using transcriptional fusions have shown that in planta growth induces the expression of pathogenicity-related genes such as the virulence genes (vir) of Agrobacterium tumefaciens, the $s y r B$ syringomycin gene of $P$. syringae pv. syringae, and the hrp genes of $P$. syringae, Erwinia amylovora, and $X$. axonopodis pv. vesicatoria $(22,29,32,35,40,42)$. Specific phenolic compounds that are released from wounded plant cells act synergistically with monosaccharides to induce the vir regulon of A. tumefaciens (4, 37). Likewise, specific phenolic glycosides such as arbutin act in concert with saccharides to activate the genes involved in synthesis of the toxin syringomycin $(22,30)$. HPLC analysis of crude leaf extracts from the host of $P$. syringae pv. syringae, sweet cherry (Prunus avium (L.) L.), indicated that cherry leaves have sufficient quantities of flavonoid glycosides to activate syringomycin synthesis (21). To date, in planta regulation of COR synthesis has not been examined.

In the current study, ice nucleation-active cor:inaZ marker-exchange derivatives of the tomato and crucifer pathogen $P$. syringae pv. tomato DC3000 were used to determine COR gene expression on various host and nonhost plants and in a basal medium supplemented with selected tomato plant constituents. The ice nuclea- 
tion reporter gene inaZ was chosen for this study because of its sensitivity and the ease with which ice nucleation activity (INA) can be detected in plant samples; furthermore, the structure and function of the ice nucleation protein itself has been shown to be unaffected by plant or environmental factors $(10,14,16,32)$. We found that the highest COR gene transcriptional activity occurred on cabbage and tomato plants. HPLC analysis of crude tomato leaf extracts and intercellular fluid (ICF) demonstrated that the active components in both preparations were primarily citric and malic acids, with minor contributions coming from shikimic and quinic acid. A mixture of organic acids at levels equivalent to that found in the plant preparations was able to duplicate this effect. When tomato plant constituents and related compounds were screened for the ability to affect COR gene transcription in vitro, the only compounds with activity at concentrations below $0.1 \mathrm{mM}$ were shikimic and quinic acids.

\section{MATERIALS AND METHODS}

Bacterial strains and media. The bacteria used in this study were $P$. syringae pv. tomato strain DC3000 and the cor:inaZ markerexchange derivatives 2017, 2022, 2024, 2025, and 2083. Each mutant carried a promoterless ice nucleation reporter gene fusion in the COR biosynthesis locus that was generated using the transposon Tn3-Spice as described previously (17). DC3000 was routinely grown at $25^{\circ} \mathrm{C}$ in nutrient broth-yeast extract-glucose (NBY) or King's B (KB) medium, while strains carrying the cor:inaZ fusions were grown at $25^{\circ} \mathrm{C}$ in $\mathrm{NBY}$ or $\mathrm{KB}$ supplemented with $100 \mu \mathrm{g}$ of spectinomycin per $\mathrm{ml}(\mathrm{KB}-\mathrm{Spc})(17)$. AB induction medium (1) contained $50 \mathrm{mM} 2$-( $N$-morpholino)ethanesulfonic acid, $17.2 \mathrm{mM} \mathrm{K} \mathrm{HPO}_{4}, 0.5 \mathrm{mM} \mathrm{NaH} \mathrm{PO}_{4}, 18.7 \mathrm{mM} \mathrm{NH} \mathrm{NH}_{4} \mathrm{Cl}$ $1.2 \mathrm{mM} \mathrm{MgSO}_{4} \cdot 7 \mathrm{H}_{2} \mathrm{O}, 2 \mathrm{mM} \mathrm{KCl}, 0.1 \mathrm{mM} \mathrm{CaCl}$, and $9 \mu \mathrm{M}$ $\mathrm{FeSO}_{4} \cdot 7 \mathrm{H}_{2} \mathrm{O}$ (pH 6.1). Strains DC3000, 2022, and 2025 were tested for the ability to use various organic compounds as sole carbon sources by placing suspensions of the bacteria $\left(5 \times 10^{3}\right.$ CFU per $10-\mu 1$ droplet) on AB agar supplemented with the test compound $(0.5 \%$ final concentration) and incubating the plates at $25^{\circ} \mathrm{C}$ for 10 days. This method is a modification of one previously described (12).

Compounds tested for induction of COR synthesis. Arbutin, caffeic acid, chlorogenic acid, chorismic acid, L-glutamine, indole3-acetic acid, L-phenylalanine, quinic acid, shikimic acid, sodium malate, sodium phospho(enol)pyruvate, and D-xylose were purchased from Sigma Chemical Co. (St. Louis). Citric acid, D-fructose, D-glucose, $\alpha$-lactose, D-maltose, D-mannose, sodium succinate, and L-tartaric acid were purchased from BDH Inc. (Toronto, Ontario, Canada). Acetosyringone, chalcone, flavanone, flavone, malic acid, octopine, and D-tartaric acid were purchased from Aldrich Chemical Co. (Milwaukee, WI). Inositol, L-isoleucine, phenylacetic acid, salicin, sodium L-glutamate, sodium pyruvate, L-tryptophan, and L-tyrosine were purchased from Nutritional Biochemicals Co. (Cleveland, OH). L-Ascorbic acid, fumaric acid, D-galactose, gallic acid, and salicylic acid were purchased from Fisher Scientific Ltd. (Unionville, Ontario, Canada). Cinnamic acid, sodium salicylate, and sucrose were purchased from J.T. Baker Inc. (Phillipsburg, NJ). Cyclohexanol, glycine, jasmonic acid, phenol, and sodium citrate were purchased from Eastman Chemical Co. (Rochester, NY), Bio-Rad Laboratories (Canada) Ltd. (Mississauga, Ontario, Canada), Apex Organics (Leicester, United Kingdom), Life Technologies Inc. (Gaithersburg, MD), and Caledon Laboratories Ltd. (Georgetown, Ontario, Canada), respectively.

Preparation of tomato leaf extract. Tomato plants (Lycopersicon esculentum Mill. cv. Bonny Best) were grown in a controlled environment chamber for 3 to 4 weeks $\left(15 \mathrm{~h}\right.$ light $\left[23^{\circ} \mathrm{C}\right] / 9 \mathrm{~h}$ dark $\left.\left[18^{\circ} \mathrm{C}\right]\right)$. Young leaves were harvested, frozen in liquid $\mathrm{N}_{2}$, ground to a fine powder, and stored at $-70^{\circ} \mathrm{C}$. For most experiments, $1 \mathrm{~g}$ of frozen tissue powder was mixed with $2 \mathrm{ml}$ of water using a mortar and pestle and then centrifuged at $9,200 \times g$ for $20 \mathrm{~min}$ $\left(4^{\circ} \mathrm{C}\right)$. The one exception was the experiment in which we determined the effect of extract concentration and plant growth conditions on INA; for this experiment, $1 \mathrm{~g}$ of tissue powder was mixed with $6 \mathrm{ml}$ of water. The supernatant was filtered through Miracloth (Calbiochem-Novabiochem Corp., San Diego, CA) and centrifuged for another $10 \mathrm{~min}$ at $9,200 \times g\left(4^{\circ} \mathrm{C}\right)$. The resulting aqueous plant extract was sterilized by filtration through a $0.45-\mu \mathrm{m}$ filter (Gelman Sciences Inc., Ann Arbor, MI), dispensed in 1-ml aliquots, and stored at $-70^{\circ} \mathrm{C}$.

Preparation of tomato ICF. ICF was obtained from 4-weekold tomato plants ('Bonny Best') by a modification of the method described by Rathmell and Sequeira (33). Strips of leaf tissue were immersed in ice-cold sterile water (approximately $2 \mathrm{~g} / 12 \mathrm{ml}$ of water in a $25-\mathrm{ml}$ vacuum flask) and infiltrated with the water by drawing a vacuum for $1 \mathrm{~min}$ and then releasing it a total of four to five times. The strips were blotted with filter paper and then centrifuged in a perforated centrifuge tube set inside a $250-\mathrm{ml}$ centrifuge bottle at $2,500 \times g$ for $10 \mathrm{~min}$ at $4^{\circ} \mathrm{C}$. The ICF was collected from the bottle, filter-sterilized, and used immediately or frozen at $-70^{\circ} \mathrm{C}$. Approximately $0.5 \mathrm{ml}$ of ICF was obtained from each gram of leaf tissue.

INA assays. A modified version of the method described by Lindgren et al. (14) was used to measure the INA resulting from expression of a cor:inaZ fusion in P. syringae pv. tomato DC3000. Twenty milliliters of KB-Spc medium was inoculated with an ice nucleation-active cor:inaZ marker-exchange derivative of DC3000 to an $A_{600}$ of 0.04 . After overnight incubation at $23^{\circ} \mathrm{C}$ with rotary shaking $(150 \mathrm{rpm})$, the bacteria were collected by centrifugation $\left(6,000 \times g, 4^{\circ} \mathrm{C}\right.$ for $\left.10 \mathrm{~min}\right)$, washed with $\mathrm{AB}$ medium, and then resuspended in $\mathrm{AB}$ medium to an $A_{600}$ of 0.5. Routinely, $0.25 \mathrm{ml}$ of sterile water, $0.25 \mathrm{ml}$ of tomato leaf extract, or $0.25 \mathrm{ml}$ of various test compounds was added to $2.25 \mathrm{ml}$ of this cell suspension in a $25-\mathrm{ml}$ flask. If necessary, the $\mathrm{pH}$ was adjusted to 5.5 after the addition of a test compound. For INA assays of ICF, $0.5 \mathrm{ml}$ of ICF was added to $2.0 \mathrm{ml}$ of the cell suspension to give a total assay volume of $2.5 \mathrm{ml}$. After a 6-h incubation period $\left(23^{\circ} \mathrm{C}, 150 \mathrm{rpm}\right)$, the cells were collected by centrifugation $\left(6,000 \times g, 4^{\circ} \mathrm{C}\right.$ for $\left.10 \mathrm{~min}\right)$ and resuspended in $2.5 \mathrm{ml}$ of $\mathrm{AB}$ medium. Tenfold serial dilutions of the suspension were made in $\mathrm{AB}$ medium, and each dilution was tested for INA at $-7^{\circ} \mathrm{C}$ by the droplet-freezing technique (14). The bacterial concentration $(\mathrm{CFU} / \mathrm{ml})$ was determined by plating the dilutions on NBY agar and incubating the plates at $25^{\circ} \mathrm{C}$ for $48 \mathrm{~h}$. INA, expressed as mean $\log _{10}$ (ice nuclei per cell) \pm standard error, was calculated as described previously (14).

In planta expression of the COR locus. Inoculum was prepared by suspending bacteria from 24 -h-old $\mathrm{KB}-\mathrm{Spc}$ agar plates in $0.01 \mathrm{M}$ potassium phosphate buffer ( $\mathrm{pH} 7.2)-0.1 \%$ Bacto-peptone (KPP) to an $A_{600}$ of $0.05\left(5 \times 10^{7} \mathrm{CFU} / \mathrm{ml}\right)$. Three-week-old tomato plants ('Bonny Best') were inoculated by gently rubbing the surfaces of the leaves with the bacterial suspension as described previously (5). At 2, 4, 8, 12, 24, 48, 72, and $144 \mathrm{~h}$ after inoculation, a leaf tissue sample $\left(1 \mathrm{~cm}^{2}\right)$ was excised from the plants, macerated in $2 \mathrm{ml}$ of KPP, and incubated on ice for $30 \mathrm{~min}$. The macerate was serially diluted in KPP and the dilutions tested for INA as described above. The INA assays were done in duplicate, and the results were expressed as the mean of three or more separate experiments. The INA of strain 2022 also was determined for the following plants: tomato (L. esculentum 'Ontario 7710' and 'CC195'), pepper (Capsicum annuum L. 'Early Niagara Giant'), soybean (Glycine max (L.) Merr. 'Harosoy'), muskmelon (Cucumis melo L. 'Earlisweet'), cucumber (Cucumis sativus L. 'National Pickling'), and cabbage (Brassica oleracea L. 'Golden Acre'). Correlation coefficients between population size and INA levels were calculated using the CORR procedure in SAS (SAS Institute, Cary, NC).

Sep-Pak cartridge isolation of organic acids. Aqueous extracts $(1 \mathrm{ml})$ and ICF samples $(6 \mathrm{ml})$ were applied to three Waters Accell Plus QMA Sep-Pak cartridges (Waters Limited, Mississauga, On- 
tario, Canada) in series that had been prewashed with $1 \mathrm{~N}$ acetic acid and then with water. After reapplying the sample twice, the cartridges were eluted with water $(15 \mathrm{ml})$ to remove nonretained material and then with $1 \mathrm{~N}$ acetic acid $(20 \mathrm{ml})$ to elute the organic acids. Dried fractions were suspended in $0.6 \mathrm{ml}$ of water and filtersterilized. The filtrate $(0.4 \mathrm{ml})$ was added to $2.1 \mathrm{ml}$ of $\mathrm{AB}$ medium and assayed for INA as described above.

HPLC. Chromatographic analysis of components in aqueous extracts and ICF from tomato leaves and preparation of fractions for assay were performed using a Waters system consisting of a U6K injector and two M510 pumps controlled by a Millennium 2010 Chromatography Manager (Waters Limited). Organic acids were analyzed, using a Shimadzu model SPD-M6A photodiode array detector (Shimadzu Scientific Instruments, Inc., Columbia MD), at $55^{\circ} \mathrm{C}$ on two Bio-Rad Aminex HPX-87H columns $(300 \times 7.8 \mathrm{~mm}$; Bio-Rad Laboratories (Canada) Ltd.) run in series and at room temperature on a Spherisorb 5- $\mu \mathrm{m} \mathrm{C}_{8}$ column $(150 \times 4.6 \mathrm{~mm}$; Waters Limited) with water containing $10 \mathrm{mM}$ trifluoroacetic acid (TFA) as eluent. A mixture of malic, citric, quinic, and shikimic acids at levels observed for the tomato extract was also chromatographed to provide fractions for assay corresponding to those obtained when the anion exchange Sep-Pak-retained material from the crude tomato extract was chromatographed. Recoveries of the organic acids were determined by analyzing aliquots of the Sep-Pak fractions. The dried HPLC fractions of the tomato extracts and of the mixture of organic acids were suspended in $0.6 \mathrm{ml}$ of water and filter-sterilized. The filtrate $(0.4 \mathrm{ml})$ was added to $2.1 \mathrm{ml}$ of $\mathrm{AB}$ medium and assayed for INA as described above.

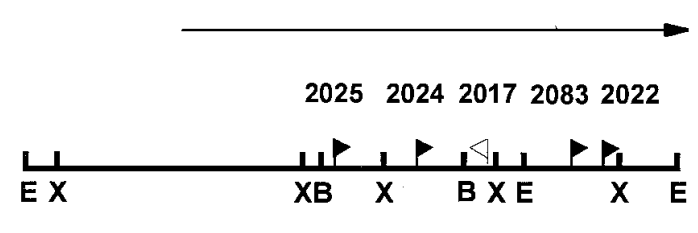

$1 \mathrm{~kb}$

Fig. 1. Restriction endonuclease map of the portion of the Pseudomonas syringae pv. tomato DC3000 coronatine gene cluster cloned into pEC18 (as indicated by the horizontal arrow above the map) (17). The location and transcriptional orientation of the Tn3-Spice insertions is indicated by the flags. A filled flag indicates insertions producing detectable ice nucleation activity. $\mathrm{E}=$ EcoRI, $\mathrm{X}=$ XhoI, and $\mathrm{B}=$ BamHI.

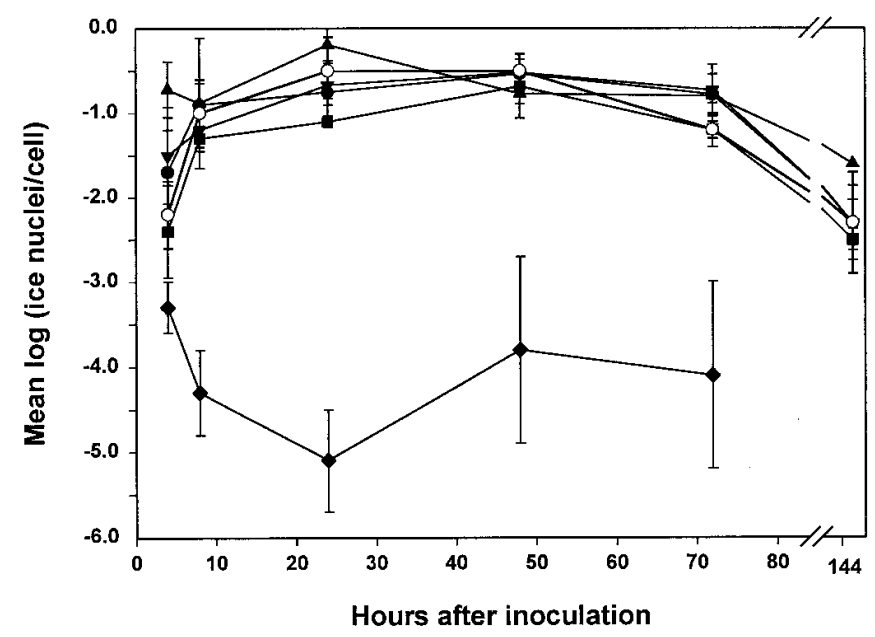

Fig. 2. In planta induction of chromosomal inaZ fusions located in the coronatine gene cluster of Pseudomonas syringae pv. tomato DC3000. The leaf surfaces of 3-week-old tomato plants ('Bonny Best') were swab-inoculated with a bacterial suspension $\left(5 \times 10^{7} \mathrm{CFU} / \mathrm{ml}\right)$ and, at the times indicated, leaf disks were excised and assayed for ice nucleation activity. Values are the means of at least three experiments. Error bars represent the standard errors of the means. $\bullet=$ strain 2022, O = strain 2022 (pEC18), $\boldsymbol{\square}=\operatorname{strain} 2083, \Delta=$ strain $2025, \nabla=$ strain 2024 , and $\diamond=\operatorname{strain} 2017$.

\section{RESULTS}

Expression of the COR locus in planta. The effect of in planta growth on COR gene expression was determined using four ice nucleation-active cor:inaZ marker-exchange derivatives of $P$. syringae pv. tomato DC3000 (strains 2022, 2024, 2025, and 2083) and one transcriptionally inactive derivative (strain 2017) (17). The location of these reporter gene fusions is shown in Figure 1. Unlike the COR gene cluster of $P$. syringae pv. glycinea PG4180, the DC3000 COR gene cluster has not undergone extensive genetic analysis. However, based on a recent comparison of the two clusters, the cor:inaZ gene fusions appear to be in the region encoding CFA synthesis (7). Each transcriptionally active DC3000 derivative exhibited INA $4 \mathrm{~h}$ after being placed on tomato leaves ('Bonny Best') (Fig. 2); low INA also occurred at $2 \mathrm{~h}$, but the results were

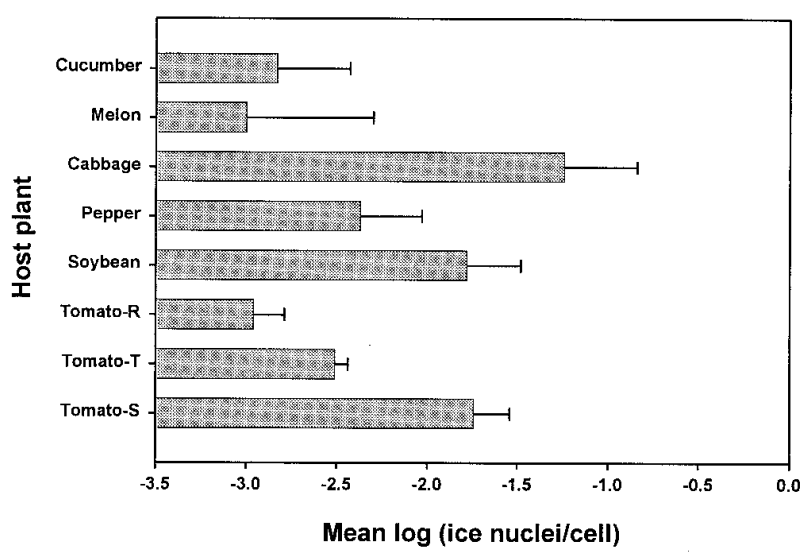

Fig. 3. Reporter gene expression on various plants inoculated with strain 2022, an ice nucleation-active cor:inaZ marker-exchange derivative of Pseudomonas syringae pv. tomato DC3000. Readings were taken $4 \mathrm{~h}$ after inoculation. Tomato-S ('Bonny Best') is highly susceptible to strain DC3000, while Tomato- $\mathrm{T}$ ('CC195') is bacterial speck tolerant and Tomato-R ('Ontario 7710') is bacterial speck resistant. Values are the means of at least three experiments. Error bars represent the standard errors of the means.

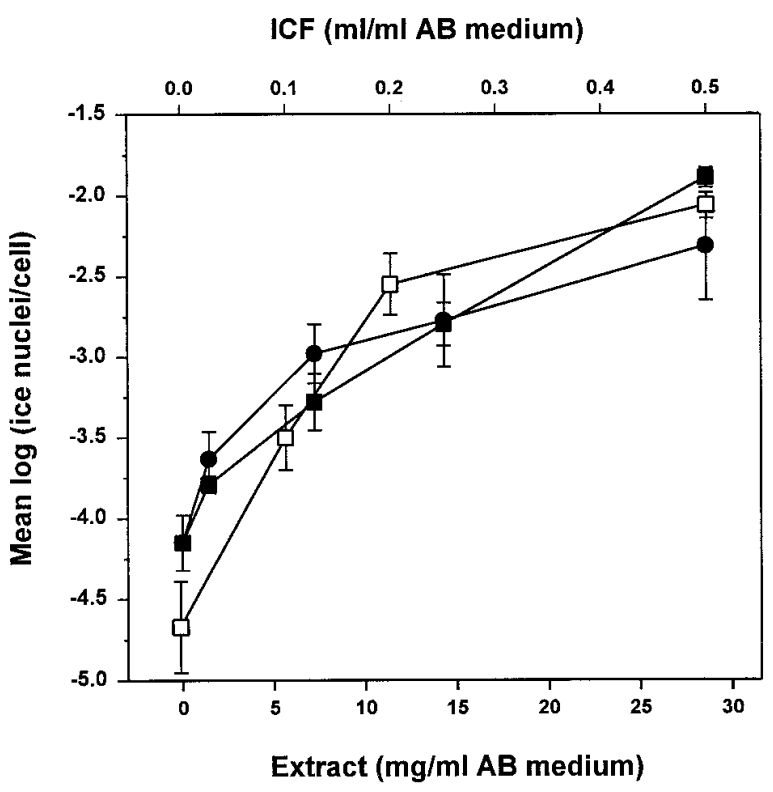

Fig. 4. Effect of crude tomato leaf extract and intercellular fluid (ICF) on the ice nucleation activity of Pseudomonas syringae pv. tomato 2022 . Crude leaf extract (expressed as $\mathrm{mg}$ fresh weight of leaf tissue per $\mathrm{ml}$ of $\mathrm{AB}$ medium) was prepared from plants incubated under normal light conditions $(\bullet)$ or in continuous darkness ( $\boldsymbol{\square})$ for the $24 \mathrm{~h}$ prior to harvest. ICF (expressed as $\mathrm{ml}$ of ICF per ml of AB medium) ( $\square$ ) was prepared as described in Materials and Methods. Approximately $0.5 \mathrm{ml}$ of ICF was generated from $1 \mathrm{~g}$ fresh weight of leaf tissue. 
not reproducible (data not shown). Expression levels peaked at 24 to $48 \mathrm{~h}$ and remained high throughout the incubation period for all strains except strain 2017. The in planta INA of strain 2022 did not change significantly when this strain was complemented with pEC18, a pLAFR1 clone of that portion of the COR gene cluster shown in Figure 1 (24); however, in planta growth of this merodiploid was significantly less than that of strain 2022 (data not shown).

In planta expression of the COR locus was not restricted to bacterial speck-susceptible cultivars of tomato. Reporter gene activity was detected $4 \mathrm{~h}$ after inoculation on every host and nonhost plant inoculated with strain 2022 (Fig. 3). However, expression was higher in the susceptible cultivar Bonny Best than in the bacterial speck-resistant cultivar Ontario 7710 or the bacterial speck-tolerant cultivar CC195. Highest activity occurred in cabbage, which is another known host for strain DC3000 (7). The only nonhost plant with an expression level equivalent to that observed on susceptible tomatoes was soybean, the natural host for another COR-producing pathogen, $P$. syringae pv. glycinea. The mean $\log _{10} \mathrm{CFU} / \mathrm{cm}^{2}$ of leaf tissue, as determined at $4 \mathrm{~h}$ after inoculation, was $5.32 \pm 0.4$ (cucumber), $5.07 \pm 0.2$ (melon), $4.52 \pm 0.2$ (soybean), $3.38 \pm 0.1$ (tomato 'Bonny Best'), $3.81 \pm 0.5$ (tomato 'Ontario 7710'), and $3.18 \pm 0.2$ (pepper). No correlation existed between population size and expression level. At $8 \mathrm{~h}$, expression levels on the various plants were not significantly different from that observed on tomato 'Bonny Best' (data not shown).

Effect of crude tomato leaf extract and ICF on COR gene expression. The INA of strains DC3000, 2017, 2022, and 2025

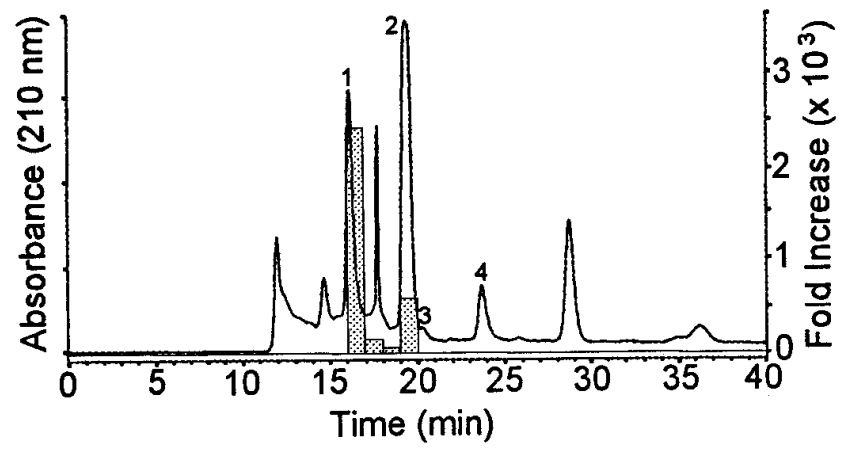

Fig. 5. High-performance liquid chromatography separation (two Bio-Rad Aminex HPX-87H columns, $300 \times 7.8 \mathrm{~mm}$, in series; $10 \mathrm{mM}$ trifluoroacetic acid at $0.6 \mathrm{ml} / \mathrm{min}$ as eluent) of the acidic fraction from a tomato leaf extract ( $0.33 \mathrm{~g}$ fresh weight) and bioassay of combined 1-min fractions from three identical chromatographic runs. The chromatogram for one of these runs is shown. Vertical bars show the fold increase (over the water control) in mean ice nuclei per cell for the material contained in fractions 16 to 30. Active fractions correspond to the retention times of citric (1), and malic (2) acids. Peaks 3 and 4 correspond to retention times of quinic and shikimic acids, respectively. Further details are in Materials and Methods.

TABLE 1. Organic acids present in 4-week-old tomato ('Bonny Best') leaves

\begin{tabular}{lccccc}
\hline $\begin{array}{l}\text { Leaf preparation/ } \\
\text { column }\end{array}$ & Malic & Citric & Quinic & Shikimic & Fumaric \\
\cline { 3 - 6 } & & & & & \\
\hline $\begin{array}{l}\text { Extract } \\
\quad \text { (a) Spherisorb C }\end{array}$ & 1,555 & 346 & $\ldots{ }^{\mathrm{y}}$ & 2.7 & $<2$ \\
$\quad \begin{array}{l}\text { (b) Bio-Rad HPX-87H } \\
\text { ICF }\end{array}$ & 1,485 & 360 & 26.1 & 2.7 & 1.5 \\
$\quad$ Bio-Rad HPX-87H & 1,748 & 982 & $\ldots$ & 3.0 & 11.1 \\
\hline
\end{tabular}

${ }^{\mathrm{x}}$ Extract was prepared from $0.33 \mathrm{~g}$ of fresh leaf tissue. Each number represents the mean for four (a) or six (b) Sep-Pak-retained fractions prepared and analyzed as described in Materials and Methods.

y Not determined due to interfering peak.

${ }^{\mathrm{z}}$ Intercellular fluid (ICF) was prepared from approximately $12 \mathrm{~g}$ of fresh tissue. Approximately $0.5 \mathrm{ml}$ of ICF was obtained from each gram of leaf tissue. Each number represents the mean for duplicate Sep-Pak-retained fractions from each of two preparations, each analyzed twice. Described in Materials and Methods. was determined after a 6-h incubation period in $\mathrm{AB}$ medium supplemented with tomato leaf extract (final concentration being the equivalent of $33 \mathrm{mg}$ of fresh leaf tissue per $\mathrm{ml}$ of $\mathrm{AB}$ medium). Only strains 2022 and 2025 had INA $(-2.24 \pm 0.55$ and $-1.24 \pm 0.14$, respectively) above background. Changing the physiological condition of the plant by incubating it without light for $24 \mathrm{~h}$ did not cause pronounced changes in COR gene expression over a wide range of leaf extract concentrations (Fig. 4). Gene activity also increased when tomato ICF was added to $\mathrm{AB}$ medium (Fig. 4). The mean $\log _{10}$ (ice nuclei per cell) in $\mathrm{AB}$ medium containing ICF $(0.5 \mathrm{ml} / \mathrm{ml}$ of $\mathrm{AB}$ medium, which is equivalent to $400 \mathrm{mg}$ fresh weight of leaf tissue per ml of $\mathrm{AB}$ medium) increased 130-fold over the control, while that in $\mathrm{AB}$ medium containing leaf extract (equivalent to $29 \mathrm{mg}$ fresh weight of leaf tissue per $\mathrm{ml}$ of medium) increased approximately 70 -fold over the control.

Identification of tomato constituents responsible for COR gene expression. Preliminary investigation of the tomato extract showed that the active principle(s) could not be extracted from water by ethyl acetate and was not retained appreciably on a SepPak $\mathrm{C}_{18}$ cartridge or a $\mu$ Bondapak $\mathrm{C}_{18}$ column (Waters Limited) with $10 \mathrm{mM}$ TFA as mobile phase, but was retained on a Accell Plus QMA Sep-Pak cartridge, indicating that the active substance(s) was acidic. The eluted acidic material was active, but no activity was observed for unretained material from an extract of fresh leaf tissue $(0.33 \mathrm{~g})$. Chromatography of QMA Sep-Pak-retained material from $1.0 \mathrm{~g}$ of fresh leaves on two Bio-Rad Aminex HPX-87H columns in series and assay of fractions indicated that material in peaks corresponding to the elution times of malic and citric acids had INA (Fig. 5). Similar conclusions were drawn when acidic fractions from leaf extracts were chromatographed on a reverse phase Spherisorb $\mathrm{C}_{8}$ column. Small amounts of quinic and shikimic acid also were observed in the tomato leaf samples. As well as confirming the identity of the peaks and providing another estimate of levels of individual components, use of a second chromatographic system helped to exclude the possibility that unknown components contributed to the bioactivity, since the order of elution of organic acids from the Bio-Rad column (citric, malic, quinic, shikimic) and the Spherisorb column (quinic, malic, shikimic, acitric) differed. Table 1 presents the results of analysis of the organic acids

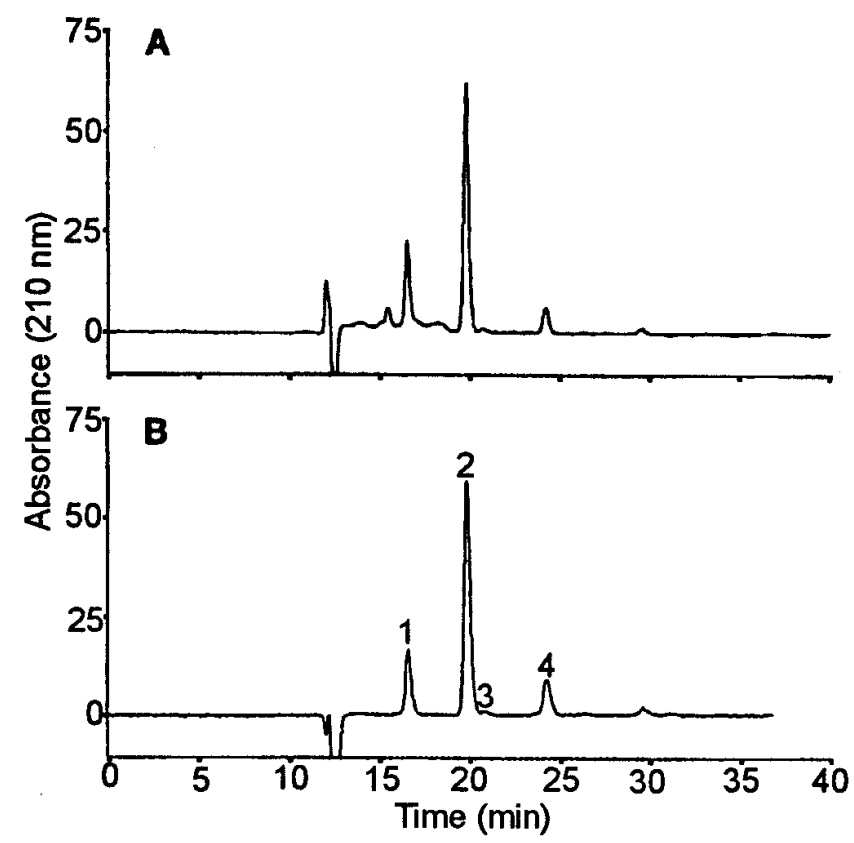

Fig. 6. High-performance liquid chromatography separation (Fig. 5 has chromatographic details) of aliquots of $\mathbf{A}$, the acidic fraction from a tomato leaf extract and B, a mixture of citric (1), malic (2), quinic (3), and shikimic (4) acids in the ratio determined for the extract. Further details are in Materials and Methods. 
in the tomato leaf extract. Based on retention time and UV spectrum, the extracts also contained fumaric acid. The chromatographic profiles for the organic acid fraction isolated from tomato leaves (Fig. 6A) were similar to those obtained for an artificial mixture of malic, citric, quinic, and shikimic acids at levels found in the plant (Fig. 6B). Comparable HPLC fractions of the tomato leaf extract and of the organic acid mixture had similar COR-inducing activity.

HPLC analysis of the ICF preparation indicated that it contained approximately $2.1 \mathrm{mM}$ malic acid and $0.85 \mathrm{mM}$ citric acid (Table 1). Levels of quinic acid in ICF could not be determined due to interference from another compound, possibly aconitic acid, that gives a stronger UV response. ICF, like tomato extract, also has a small quantity of fumaric acid $(16 \mu \mathrm{m})$.

Induction of COR gene expression by tomato plant constituents and related compounds. A group of compounds commonly found in tomato leaves and fruit $(8,31)$ was screened for their ability to induce expression of the cor:inaZ fusion in strain 2022 (Table 2). All assays were performed in AB minimal medium (1). The sugars glucose, sucrose, inositol, and galactose increased expression of the reporter gene by at least 1,500-fold, but fructose only slightly enhanced INA (17-fold) when tested at the $5.5-\mathrm{mM}$ level. No activity $(-5.8 \pm 0.8)$ occurred when the glucose assays were performed in KB basal medium. Citric acid and malic acid, two organic acids that were present in relatively high concentrations in tomato plant extracts $(5.5 \mu \mathrm{mol}$ and $34 \mu \mathrm{mol} / \mathrm{g}$ of fresh leaf tissue, respectively; Table 1), also strongly enhanced INA when tested at the 5-mM level, but not to the same degree as the sugars glucose, inositol, and sucrose. Several other organic acids, not as abundant in tomato leaf tissue as citric and malic acids, also influenced reporter gene expression, with shikimic acid having the most pronounced effect. At concentrations of $0.5 \mathrm{mM}$ or lower, the only compounds with activity were shikimic acid, quinic acid, and glucose. When these three compounds were tested over a range of concentrations, the organic acids were still active at $0.05 \mathrm{mM}$ (Table 3). A mixture of $0.1 \mathrm{mM}$ glucose and $0.05 \mathrm{mM}$ shikimic acid had 10 -fold more activity $(-2.04 \pm 0.26)$ than $0.05 \mathrm{mM}$ shikimic acid alone; reducing the shikimic acid concentration in the mixture to $0.01 \mathrm{mM}$ resulted in activity $(-4.66 \pm 0.22)$ close to that of the control. The INA of strain 2025 incubated in the presence of glucose, citric acid, pyruvate, succinate, glutamate, quinic acid, or shikimic acid (at $5 \mathrm{mM}, 0.5 \mathrm{mM}$, or $0.1 \mathrm{mM}$ ) was equivalent to that observed for strain 2022 (data not shown). Strain 2017 exhibited

TABLE 2. Ice nucleation activity of Pseudomonas syringae pv. tomato 2022 incubated in the presence of compounds common to tomato plants

\begin{tabular}{lcccr}
\hline & & \multicolumn{2}{c}{ Mean $\log _{10}$ ice nuclei/CFU } & Fold \\
\cline { 3 - 4 } Compound & Growth & Treatment & Control & Forease \\
\hline $5.5 \mathrm{mM}$ D-Fructose & + & $-3.58 \pm 0.58(6)^{\mathrm{z}}$ & $-4.82 \pm 0.24(6)$ & 17 \\
$5.5 \mathrm{mM}$ D-Galactose & + & $-1.44 \pm 0.21(3)$ & $-4.62 \pm 0.43(3)$ & 1,517 \\
$5.5 \mathrm{mM}$ D-Glucose & + & $-0.56 \pm 0.30(13)$ & $-4.93 \pm 0.81(26)$ & 23,335 \\
$5.5 \mathrm{mM}$ Inositol & + & $-0.73 \pm 0.23(4)$ & $-5.16 \pm 0.07(4)$ & 26,792 \\
$2.9 \mathrm{mM}$ Sucrose & + & $-0.69 \pm 0.06(4)$ & $-4.69 \pm 0.19(4)$ & 10,000 \\
$6.7 \mathrm{~m}$ M D-Xylose & + & $-4.86 \pm 0.11(2)$ & $-5.08 \pm 0.36(2)$ & 2 \\
$5 \mathrm{mM}$ Citric acid & + & $-2.09 \pm 0.55(8)$ & $-5.32 \pm 0.28(8)$ & 1,694 \\
$5 \mathrm{mM}$ Fumaric acid & + & $-2.26 \pm 0.32(4)$ & $-4.77 \pm 0.62(4)$ & 324 \\
$5 \mathrm{mM}$ Malic acid & + & $-1.58 \pm 0.08(2)$ & $-4.81 \pm 1.0(2)$ & 1,000 \\
$5 \mathrm{mM}$ D-Tartaric acid & + & $-3.79 \pm 0.16(2)$ & $-5.36 \pm 0.30(2)$ & 37 \\
$5 \mathrm{mM}$ Quinic acid & - & $-0.99 \pm 0.90(4)$ & $-4.6 \pm 0.80(4)$ & 4,085 \\
$5 \mathrm{mM}$ Shikimic acid & - & $-0.22 \pm 0.31(4)$ & $-4.90 \pm 0.79(4)$ & 47,863 \\
$5 \mathrm{mM}$ Pyruvate & + & $-0.86 \pm 0.57(2)$ & $-4.03 \pm 0.17(2)$ & 1,510 \\
$5 \mathrm{mM}$ Succinate & + & $-1.05 \pm 0.10(2)$ & $-4.03 \pm 0.17(2)$ & 955 \\
$3 \mathrm{mM}$ Glutamate & + & $-0.50 \pm 0.09(2)$ & $-4.03 \pm 0.17(2)$ & 3,443 \\
$3 \mathrm{mM}$ Glutamine & + & $-1.02 \pm 0.46(3)$ & $-5.10 \pm 0.09(3)$ & 12,078 \\
\hline
\end{tabular}

y Strain 2022 was tested for the ability to use these compounds as sole carbon sources in $\mathrm{AB}$ minimal medium. + = growth and $-=$ no growth after 10 days of incubation at $25^{\circ} \mathrm{C}$.

${ }^{\mathrm{z}}$ Results are expressed as the mean \pm standard error. Values in brackets indicate the number of times the assay was repeated. no INA when assayed in $\mathrm{AB}$ medium containing $5.5 \mathrm{mM}$ D-glucose, $5 \mathrm{mM}$ pyruvate, $5 \mathrm{mM}$ succinate, $3 \mathrm{mM}$ glutamate, or $0.1 \mathrm{mM}$ shikimic acid (data not shown). With the exception of shikimic acid and quinic acid, all of the compounds listed in Table 1 supported the growth of 2022, 2025, 2017, and the parent strain DC3000. None of the following compounds, which were tested at $0.1-\mathrm{mM}$ concentration, affected coronatine synthesis: $\alpha$-lactose, D-maltose, D-mannose, glycine, L-isoleucine, L-phenylalanine, L-tryptophan, L-tyrosine, octopine, indole-3-acetic acid, L-ascorbic acid, caffeic acid, chlorogenic acid, chorismic acid, cinnamic acid, gallic acid, jasmonic acid, phenylacetic acid, sodium phospho(enol)pyruvate, salicylic acid, L-tartaric acid, phenol, arbutin, acetosyringone, chalcone, flavanone, flavone, salicin, and cyclohexanol.

\section{DISCUSSION}

The COR locus of the tomato and crucifer pathogen $P$. syringae pv. tomato DC3000, as represented by four transcriptionally active cor:inaZ fusions, was strongly activated in planta and in a basal medium containing tomato leaf extract or ICF. Although every plant inoculated with strain DC3000 carrying a cor:inaZ fusion had COR-inducing activity, maximal expression, measured $4 \mathrm{~h}$ after inoculation, occurred on cabbage, the natural host for DC3000 (7). Cucumber and melon, plants that are not natural hosts for any of the COR-producing pathogens, had the least signal activity. A weaker response also was noted with resistant or tolerant cultivars of tomato. Likewise, Krzesinska et al. (13) noted that expression of the syringomycin gene $s y r B$ was more pronounced in those cherry genotypes susceptible to bacterial canker and gummosis. Plant-related differences in COR gene expression, which did not correlate with differences in bacterial population levels, may reflect qualitative or quantitative differences in plant signal molecules. Alternatively, weaker expression in resistant and tolerant cultivars may be due to the effect of host defenses on general bacterial metabolism or global regulatory mechanisms. Strong in planta expression soon after inoculation lends support to an earlier study that demonstrated that COR is required for the initial establishment of infection on the host plant (20). Mittal and Davis (20) have suggested that COR may suppress the activation of defense-related genes.

The components of tomato leaf extract and ICF that were responsible for the INA activity of the cor:inaZ fusions were acidic in nature and water soluble. The highest INA occurred in those HPLC fractions containing malic and citric acids. Extract analyses and bioassays indicated that tomato leaves have sufficient quantities of these two acids for induction of toxin synthesis. In an earlier study, we demonstrated that malic and citric acids, which are the predominant organic acids in both tomato leaves and fruit $(8,31)$, are strong chemoattractants for $P$. syringae pv. tomato (6). Citric acid at a high concentration in a minimal growth medium also will elevate expression of the hrp genes of $P$. syringae pv. phaseolicola (32). Quinic and shikimic acids had much higher COR-inducing activity than malic or citric acid, but they were not present in a

TABLE 3. Effect of the concentration of glucose, shikimic acid, and quinic acid on coronatine induction

\begin{tabular}{llll}
\hline & \multicolumn{3}{c}{ Mean $\log _{10}$ ice nuclei/CFU } \\
\cline { 2 - 4 } Concentration & \multicolumn{1}{c}{ Shikimic acid } & \multicolumn{1}{c}{ Quinic acid } & \multicolumn{1}{c}{ Glucose } \\
\hline 0 & $-4.90 \pm 0.79$ & $-5.03 \pm 0.73$ & $-4.93 \pm 0.81$ \\
$0.01 \mathrm{mM}$ & $-4.71 \pm 0.29(2)^{\mathrm{x}}$ & $-4.60 \pm 0.37(3)$ & $\ldots{ }^{\mathrm{y}}$ \\
$0.05 \mathrm{mM}$ & $-3.13 \pm 0.43(59)$ & $-2.84 \pm 0.07(155)$ & $\ldots$ \\
$0.10 \mathrm{mM}$ & $-2.54 \pm 0.66(230)$ & $-2.33 \pm 0.19(505)$ & $-5.14 \pm 0.49(0)$ \\
$0.5 \mathrm{mM}$ & $-1.48 \pm 0.17(2,636)$ & $-2.04 \pm 0.29(995)$ & $-2.55 \pm 1.0(238)$ \\
$5.0 \mathrm{mM}^{\mathrm{z}}$ & $-0.22 \pm 0.31(47,830)$ & $-0.99 \pm 0.90(4,085)$ & $-0.56 \pm 0.3(23,335)$ \\
\hline
\end{tabular}

${ }^{\mathrm{w}}$ Each assay was repeated two to six times.

$\mathrm{x}$ Number in parenthesis is the fold increase in ice nucleation activity.

y Not determined.

${ }^{\mathrm{z}}$ For glucose, the concentration was $5.5 \mathrm{mM}$. 
high enough concentration in either foliar extract or ICF to transcriptionally activate toxin genes. Although the ratio of malic to citric acid in leaf extracts was similar to that found by Quiros et al. (31), the amount of quinic acid was much lower. The level of this acid corresponded more closely to that reported by Tarrach and Herrmann (38), while that of shikimic acid was similar to that found by Mollenhauer et al. (23). Fuchs and De Vries (9) showed that quinic acid is readily converted to shikimic acid in both healthy and Fusarium-infected tomato plants. A variety of reasons including plant age, variety, and growth conditions may account for the differences in relative amounts of the organic acids found in this and other studies.

The primary sugars found in tomato leaves and fruit are glucose, fructose, inositol, and sucrose (8,31). Although these sugars, with the exception of fructose, were strong inducers of toxin production, nonacidic fractions from our tomato leaf preparations did not exhibit activity. Perhaps the presence of fructose, which has been shown to be inhibitory to COR synthesis $(26,27)$, in these fractions could account for our results. Unlike malic and citric acids, glucose and fructose do not elicit a strong chemotactic response from the pathogen (6). Furthermore, our study has shown that COR genes, unlike the vir genes of A. tumefaciens (29), the nod genes of Rhizobium spp. (29), and the syringomycin $s y r B$ gene of $P$. syringae pv. syringae (22), do not respond to several of the more commonly occurring plant phenolics. Using HPLC analysis and the inaZ reporter gene assay system, we did not detect any specific, tomato-associated phenolics that induced toxin production. However, shikimic and quinic acids, the strongest COR inducers for strain DC3000, are part of the shikimic acid pathway, which is the primary route for synthesis of phenylalanine and phenols in plants (11). We also found that the signal activity of shikimic acid, like that of the $s y r B$ - and vir-inducing phenolics $(22,36)$, increased significantly in the presence of low levels of sugar. Cangelosi et al. (4) noted that some of the sugars affecting vir gene expression, like those influencing COR gene expression, can act independently of the phenolic inducers.

In summary, we have shown that COR synthesis by $P$. syringae pv. tomato DC3000, which starts soon after invasion of the host plant, is influenced by a number of organic compounds common to tomato. Although HPLC analysis indicated that the citric and malic acid content of our plant preparations, including ICF, was sufficient to induce toxin production, these organic acids may not be the primary plant compounds responsible for COR gene activation in planta. The effective induction at low concentrations $(50 \mu \mathrm{M})$ by shikimic and quinic acids, two compounds that are not used as sole carbon sources by $P$. syringae pv. tomato DC3000, suggests that they may be signal molecules. In planta synthesis of COR appears to be under the control of a complex and multistep regulatory system involving many nutritional and environmental factors.

\section{ACKNOWLEDGMENTS}

We thank T. Ainsworth and L. M. Ross for their able assistance and valuable discussions.

\section{LITERATURE CITED}

1. Ankenbauer, R. G., and Nester, E. W. 1990. Sugar-mediated induction of Agrobacterium tumefaciens virulence genes: Structural specificity and activities of monosaccharides. J. Bacteriol. 172:6442-6446.

2. Bender, C. L., Malvick, D. K., and Mitchell, R. E. 1989. Plasmid-mediated production of the phytotoxin coronatine in Pseudomonas syringae pv. tomato. J. Bacteriol. 171:807-812.

3. Bender, C. L., Stone, H. E., Sims, J. J., and Cooksey, D. A. 1987. Reduced pathogen fitness of Pseudomonas syringae pv. tomato Tn5 mutants defective in coronatine production. Physiol. Mol. Plant Pathol. 30:273-283.

4. Cangelosi, G. A., Ankenbauer, R. G., and Nester, E. W. 1990. Sugars induce the Agrobacterium virulence genes through a periplasmic binding protein and a transmembrane signal protein. Proc. Natl. Acad. Sci. U.S.A. 87:6708-6712.
5. Cuppels, D. A. 1986. Generation and characterization of $\operatorname{Tn} 5$ insertion mutations in Pseudomonas syringae pv. tomato. Appl. Environ. Microbiol. 51:323-327.

6. Cuppels, D. A. 1988. Chemotaxis by Pseudomonas syringae pv. tomato. Appl. Environ. Microbiol. 54:629-632.

7. Cuppels, D. A., and Ainsworth, T. 1995. Molecular and physiological characterization of Pseudomonas syringae pv. tomato and Pseudomonas syringae pv. maculicola strains that produce the phytotoxin coronatine. Appl. Environ. Microbiol. 61:3530-3536.

8. Davies, J. N., and Hobson, G. E. 1981. The constituents of tomato fruit-The influence of environment, nutrition, and genotype. CRC Crit. Rev. Food Sci. Nutr. 15:205-280.

9. Fuchs, A., and De Vries, F. W. 1969. Metabolism of radioactively labeled quinic acid and shikimic acid in healthy and Fusarium-infected tomato plants. Neth. J. Plant Pathol. 75:186-192.

10. Georgakopoulos, D. G., Hendson, M., Panopoulos, N. J., and Schroth, M. N. 1994. Analysis of expression of a phenazine biosynthesis locus of Pseudomonas aureofaciens PGS12 on seeds with a mutant carrying a phenazine biosynthesis locus-ice nucleation reporter gene fusion. Appl. Environ. Microbiol. 60:4573-4579.

11. Hess, D. 1975. Plant Physiology: Molecular, Biochemical, and Physiological Fundamentals of Metabolism and Development. Springer-Verlag, New York.

12. Jackson, D. J., Gray, D. A., Morris, V. L., and Cuppels, D. A. 1992. Identification of a DNA region required for growth of Pseudomonas syringae pv. tomato. Can. J. Microbiol. 38:883-890.

13. Krzesinska, E. Z., Azarenko, A. N., and Gross, D. C. 1993. Inducing the syrB gene in Pseudomonas syringae pv. syringae in twig extracts from cherry genotypes. HortScience 28:335-337.

14. Lindgren, P. B., Frederick, R., Govindarajan, A. G., Panopoulos, N. J., Staskawicz, B. J., and Lindow, S. E. 1989. An ice nucleation reporter gene system: Identification of inducible pathogenicity genes in Pseudomonas syringae pv. phaseolicola. EMBO (Eur. Mol. Biol. Organ.) J. 8:1291-1301.

15. Liyanage, H., Palmer, D. A., Ullrich, M., and Bender, C. L. 1995. Characterization and transcriptional analysis of the gene cluster for coronafacic acid, the polyketide component of the phytotoxin coronatine. Appl. Environ. Microbiol. 61:3843-3848.

16. Loper, J., and Henkels, M. D. 1997. Availability of iron to Pseudomonas fluorescens in rhizosphere and bulk soil evaluated with an ice nucleation reporter gene. Appl. Environ. Microbiol. 63:99-105.

17. Ma, S.-W., Morris, V. L., and Cuppels, D. A. 1991. Characterization of a DNA region required for production of the phytotoxin coronatine by Pseudomonas syringae pv. tomato. Mol. Plant-Microbe Interact. 4:69-74.

18. Mitchell, R. E. 1982. Coronatine production by some phytopathogenic pseudomonads. Physiol. Plant Pathol. 20:83-89.

19. Mitchell, R. E., Hale, C. N., and Shanks, J. C. 1983. Production of different pathogenic symptoms and different toxins by strains of Pseudomonas syringae pv. tomato not distinguishable by gel-immunodiffusion assay. Physiol. Plant Pathol. 23:315-322.

20. Mittal, S., and Davis, K. R. 1995. Role of the phytotoxin coronatine in the infection of Arabidopsis thaliana by Pseudomonas syringae pv. tomato. Mol. Plant-Microbe Interact. 8:165-171.

21. Mo, Y.-Y., Geibel, M., Bonsall, R. F., and Gross, D. C. 1995. Analysis of sweet cherry (Prunus avium L.) leaves for plant signal molecules that activate the $\operatorname{syr} B$ gene required for synthesis of the phytotoxin, syringomycin, by Pseudomonas syringae pv. syringae. Plant Physiol. 107:603-612.

22. Mo, Y.-Y., and Gross, D. C. 1991. Plant signal molecules activate the $s y r B$ gene, which is required for syringomycin production by Pseudomonas syringae pv. syringae. J. Bacteriol. 173:5784-5792.

23. Mollenhauer, C., Smart, C. C., and Amrhein, N. 1987. Glyphosate toxicity in the shoot apical region of the tomato plant. I. Plastid swelling is the initial ultrastructural feature following in vivo inhibition of 5-enolpyruvylshikimic acid 3-phosphate synthase. Pest. Biochem. Physiol. 29:55-65.

24. Moore, R. A., Starratt, A. N., Ma, S.-W., Morris, V. L., and Cuppels, D. A. 1989. Identification of a chromosomal region required for biosynthesis of the phytotoxin coronatine by Pseudomonas syringae pv. tomato. Can. J. Microbiol. 35:910-917.

25. Palmer, D. A., and Bender, C. L. 1993. Effects of environmental and nutritional factors on production of the polyketide phytotoxin coronatine by Pseudomonas syringae pv. glycinea. Appl. Environ. Microbiol. 59:1619-1626.

26. Palmer, D. A., and Bender, C. L. 1995. Ultrastructure of tomato leaf tissue treated with the pseudomonad phytotoxin coronatine and comparison with methyl jasmonate. Mol. Plant-Microbe Interact. 8:683-692.

27. Palmer, D. A., Bender, C. L., and Sharma, S. B. 1997. Use of Tn5-gusA5 to investigate environmental and nutritional effects on gene expression in the coronatine biosynthetic gene cluster of Pseudomonas syringae pv. glycinea. Can. J. Microbiol. 43:517-525.

28. Parry, R. J., and Mafoti, R. 1986. Biosynthesis of coronatine, a novel 
polyketide. J. Am. Chem. Soc. 108:4681-4682.

29. Peters, N. K., and Verma, D. P. S. 1990. Phenolic compounds as regulators of gene expression in plant-microbe interactions. Mol. Plant-Microbe Interact. 3:4-8.

30. Quigley, N. B., and Gross, D. C. 1994. Syringomycin production among strains of Pseudomonas syringae pv. syringae: Conservation of the syrB and $\operatorname{syr} D$ genes and activation of phytotoxin production by plant signal molecules. Mol. Plant-Microbe Interact. 7:78-90.

31. Quiros, C. F., Stevens, M. A., Rick, C. M., and Kok-Yokomi, M. L. 1977. Resistance in tomato to the pink form of the potato aphid (Macrosiphum euphorbiae Thomas): The role of anatomy, epidermal hairs, and foliage composition. J. Am. Soc. Hortic. Sci. 102:166-171.

32. Rahme, L. G., Mindrinos, M. N., and Panopoulos, N. J. 1992. Plant and environmental sensory signals control the expression of hrp genes in Pseudomonas syringae pv. phaseolicola. J. Bacteriol. 174:3499-3507.

33. Rathmell, W. G., and Sequeira, L. 1974. Soluble peroxidase in fluid from the intercellular spaces of tobacco leaves. Plant Physiol. 53:317-318.

34. Schulte, R., and Bonas, U. 1992. A Xanthomonas pathogenicity locus is induced by sucrose and sulfur-containing amino acids. Plant Cell 4:79-86.

35. Schulte, R., and Bonas, U. 1992. Expression of the Xanthomonas campestris pv. vesicatoria hrp gene cluster, which determines pathogenicity and hypersensitivity on pepper and tomato, is plant inducible. J. Bacteriol. 174:815-823.

36. Shimoda, N., Toyoda-Yamamoto, A., Nagamine, J., Usami, S., Katayama, M., Sakagami, Y., and Machida, Y. 1990. Control of expression of Agrobacterium vir genes by synergistic actions of phenolic signal molecules and monosaccharides. Proc. Natl. Acad. Sci. U.S.A. 87:6684-6688.

37. Stachel, S. E., Messens, E., Van Montagu, M., and Zambryski, P. 1985. Identification of the signal molecules produced by wounded plant cells that activate T-DNA transfer in Agrobacterium tumefaciens. Nature 318: 624-629.

38. Tarrach, F., and Herrmann, K. 1986. Organische Säuren der Gemüsearten. IV. Die Veränderungen der Säuren sowie der Zucker in Tomaten, Gemüsepaprika und Gurken während Entwicklung und Reife. Z. Lebensm. Unters. Forsch. 183:410-415.

39. Ullrich, M., Peñaloza-Vázquez, A., Bailey, A. M., and Bender, C. L. 1995. A modified two-component regulatory system is involved in temperature-dependent biosynthesis of the Pseudomonas syringae phytotoxin coronatine. J. Bacteriol. 177:6160-6169.

40. Wei, Z.-M., Sneath, B. J., and Beer, S. V. 1992. Expression of Erwinia amylovora hrp genes in response to environmental stimuli. J. Bacteriol. 174:1875-1882.

41. Wiebe, W. L., and Campbell, R. N. 1993. Characterization of Pseudomonas syringae pv. maculicola and comparison with $P$. s. tomato. Plant Dis. 77:414-419.

42. Xiao, Y., Lu, Y., Heu, S., and Hutcheson, S. W. 1992. Organization and environmental regulation of the Pseudomonas syringae pv. syringae 61 hrp cluster. J. Bacteriol. 174:1734-1741.

43. Young, S. A., Park, S. K., Rodgers, C., Mitchell, R. E., and Bender, C. L. 1992. Physical and functional characterization of the gene cluster encoding the polyketide phytotoxin coronatine in Pseudomonas syringae pv. glycinea. J. Bacteriol. 174:1837-1843. 